\title{
Ethanol Extract Activity of Pegagan Embun (Hydrocotyle sibthorpioides L.) Against Hematopoietic on Anemic Male White Mice
}

\author{
Elidahanum Husni*, Dwisari Dillasamola, Elsa Badriyya, Resta Angelia, Yufri Aldi
}

Elidahanum Husni*, Dwisari Dillasamola, Elsa Badriyya, Resta Angelia, Yufri Aldi

Faculty of Pharmacy, University Andalas, INDONESIA.

\section{Correspondence}

\section{Elidahanum Husni}

Faculty of Pharmacy, University Andalas, INDONESIA.

E-mail: elidahanumhusni@phar.unand.ac.id History

- Submission Date: 18-02-2021;

- Review completed: 22-03-2021;

- Accepted Date: 07-04-2021.

DOI : 10.5530/pj.2021.13.111

Article Available online

http://www.phcogj.com/v13/i4

\section{Copyright}

(c) 2021 Phcogi.Com. This is an openaccess article distributed under the terms of the Creative Commons Attribution 4.0 International license.

\begin{abstract}
Introduction: Pegagan embun (Hydrocotyle sibthorpioides L.) is known to have many benefits, including as a blood booster. This study aims to determine the activity of pegagan embun (Hydrocotyle sibthorpioides L.) on the formation of red blood cells. The parameters include the number of erythrocytes, reticulocytes, hemoglobin levels, and hematocrit values in anemic male white mice induced by chloramphenicol $130 \mathrm{mg} / \mathrm{kg}$ for 14 days. Methods: Anemic mice consisted of 4 groups, namely the first group was given physiological $\mathrm{NaCl}$, the second, third, and fourth groups were given ethanol extract of pegagan embun (Hydrocotyle sibthorpioides L.) at a dose of 10,50 and $100 \mathrm{mg} / \mathrm{kgper}$ oral every day, for 14 days. Observations were made on days $0,14,21$, and 28 . Results: The results showed that administration of pegagan embun extracts at a dose of 10,50 , and $100 \mathrm{mg} / \mathrm{kgto}$ anemic male white mice significantly increase the number of erythrocyte cells, the number of reticulocytes, the hemoglobin levels, and the hematocrit values $(p<0.05)$. Increasing the dose and duration of pegagan embun extract administration could provide a more significant increase in the hematopoietic parameters ( $p<0.05)$. Conclusion:It can be concluded that the extract of pegagan embun (Hydrocotyle sibthorpioides L.) can be used to treat anemia in male white mice.
\end{abstract}

Key words: Extract of Hydrocotyle sibthorpioides L., Erythrocytes, Reticulocytes, Hemoglobin, Hematocrit.

\section{INTRODUCTION}

Blood is an essential component of living things that function as a medium of communication between cells. Blood carries $\mathrm{O}_{2}$ (oxygen) from the lungs to tissues and $\mathrm{CO}_{2}$ (carbon dioxide) from the tissues throughout the body to the lungs to be excreted. The next function is to carry nutrients from the digestive tract to the body tissues and then deliver the residualof metabolism through secretory organs such as the kidneys. It also functions as the delivery of hormones and blood clotting components ${ }^{1}$. Blood consists of various parts, including erythrocytes, leukocytes, and platelets ${ }^{2}$. Red blood cells (erythrocytes) contain hemoglobin, which allows the blood to carry oxygen from the lungs and deliver it to all body tissues. ${ }^{3}$ Hemoglobin consists of Fe (iron), protoporphyrin, and globin $(1 / 3 \text { of the weight of } \mathrm{Hb} \text { consists of } \mathrm{Fe})^{4}$. Iron $(\mathrm{Fe})$ is an essential element in the process of forming hemoglobin $(\mathrm{Hb})$. Hemoglobin $(\mathrm{Hb})$ is a colorant found in red blood cells, which has a function to transport oxygen $\left(\mathrm{O}_{2}\right)$ and carbon dioxide $\left(\mathrm{CO}_{2}\right)$ in the body. ${ }^{5}$

A decrease in the number of red blood cells is called anemia. Anemia is a condition in which decreased hemoglobin $(\mathrm{Hb})$, hematocrit, and red blood cell counts are below normal values ${ }^{6}$. Anemia occurs when the hemoglobin level is below $12 \mathrm{~g} /$ $\mathrm{dl}$ in women, and $14 \mathrm{~g} / \mathrm{dl}$ in men, the diagnosis of anemia is not only seen from the number of erythrocytes and hemoglobin levels but also the value of the hematocrit and the number of reticulocytes.? These blood cells have a certain age, so it needs new blood cells called hematopoiesis ${ }^{8}$. Hematopoietic comes from Greek (haema = blood and poiesis = formation), which plays a role in forming red blood cells and white blood cells. ${ }^{9}$ The mature red blood cells are 120 days old, will be removed from the bone marrow, and thenthey are disintegrated and died. The dead red blood cells are replaced by new cells that are regenerated by the bone marrow ${ }^{10}$.

The hematopoietic is highly dependenton the environment or cytokines as well as hematopoietic growth factors (e.g., Interleukin3 (IL3), Granulocytemacrophage colony-stimulating factor (GM-CSF), or GCSF) $)^{11}$. Pegagan embun in China is used to treat various diseases and for flavor enhancement in ethnic foods. Traditionally, pegagan embun has been used to treat psoriasis, dysentery, whooping cough, jaundice, B hepatic, fever, edema, and sore throat. ${ }^{12}$. In previous research, pegagan embun (Hydrocotyle sibthorpioides L.) was shown to have an antidiuretic effect and was effective in external administration for skin tumors and increased phagocytic activity and immune function ${ }^{13}$. Based on previous study, Pegagan embun also shown to have immunostimulatory activity $^{14}$ and an anti-inflammatory effect on topical application ${ }^{15}$. In Indonesia, one of the traditional plants used to treat anemia and blood booster

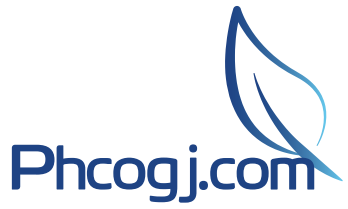

Cite this article: Husni E, Dillasamola D, Badriyya E, Angelia R, Aldi Y. Ethanol Extract Activity of Pegagan Embun (Hydrocotyle sibthorpioides L.) Against Hematopoietic on Anemic Male White Mice. Pharmacog J. 2021;13(4): 866-873. 
is pegagan embun16. But there has been no research on the ethanol extract of pegagan embun on anti-anemia activity.

\section{MATERIAL ANDS METHODS}

\section{Time and location of research}

This research was conducted for four months at the Central Laboratory and Serology-Immunology Laboratory, Faculty of Pharmacy, Andalas University.

\section{Tools}

The tools used in this study were a Triple Beam Balance (Ohause ${ }^{\varpi}$ ) animal scale, a Denver Instrument ${ }^{\circledR}$ analytical scale, a maceration bottle, a mortar, a stamper, a mouse cage, a place for eating and drinking mice, a dropper pipette, funnel, Pyrex ${ }^{\oplus}$ measuring cup, tube Pyrex ${ }^{\oplus}$ reaction, Pyrex $^{\oplus}$ glass beaker, vial, spatula, gloves, mask, syringe, needle, surgical scissors, wire. Rotary evaporator buchi ${ }^{\oplus}$ TLC plate, Easy Touch GHb, hemoglobin test strip, hemoglobin pipette, counting room.Hematocrit micropipette, hematocrit centrifuge, spectrophotometer.Erythrocyte pipette, hemocytometer, slide, cover glass, microscope, laboratory coat, tissue, writing instruments, and calculators.

\section{Materials}

The materials used were pegagan embun (Hydrocotyle sibthorpioides L.), $\mathrm{Na} \mathrm{CMC}$, aquadest (Bratco Chemika), 70\% ethanol (Brataco Chemika), hayem solution (PT. Segara Husada Mandiri No. Batch 600418-HY), brilliant cresylblue solution. $1 \%$, chloramphenicol ${ }^{\circ}$, quercetin, $n$-hexane, ethyl acetate, and male white mice weighing 20-30 grams.

\section{Extract making}

The extract was made by maceration using $70 \%$ ethanol; 848.48 grams of Simplicia was put into a maceration bottle. Added with $70 \%$ ethanol with a ratio of 1: 10 while stirring occasionally, then stored in a place protected from direct sunlight. Soaking is carried out for 24 hours, filtered to obtain macerate. This filtering process is repeated three times using the same type of solvent. All macerates were evaporated and concentrated with a rotary evaporator until a thick extract was obtained. The yield obtained is weighed and recorded ${ }^{16}$.

\section{Preparation of experimental animals}

The experimental animals used were 25 white mice aged 2-3 months with bodyweight between 20-30 grams, divided into five groups, and each group consisting of 5 mice. Before being given the treatment, the mice were acclimatized for seven days in the research room and were given food and drink according to the standard.

\section{Dosage circumvention}

The doses of the ethanol extract of pegagan embun used in this study consisted of 10,50 , and $100 \mathrm{mg} / \mathrm{kg}$.

\section{Measuring erythrocytes}

The erythrocyte pipette is first rinsed using a hayem solution. The mice's tails were cut, clean the blood on the tails that were cut using a tissue, let the blood come out then sucked using an erythrocyte pipette until the mark was $0.5 \mu$ the excess blood attached to the tip of the pipette was removed with tissue again. Then enter the pipette into the hayem solution while holding the blood on the $0.5 \mu \mathrm{l}$ line, then suck the hayem solution until the $101 \mu \mathrm{l}$ mark line. The pipette is lifted from the solution, cover the tip of the pipette with your fingers and remove the suction rubber, shake the pipette for 15-30 seconds, the calculation is carried out under a microscope with 400x magnification.

\section{Measuring reticulocytes}

Into the tube, enter the blood and dye (brilliant cresyl blue) with a ratio of 1: 1, mix well, leave for 15 minutes so that the coloring is perfect. Make a smear mixture, let it dry in the air. Examine it under a microscope at 100x magnification. Erythrocytes appear light blue, and reticulocytes will arrive as cells containing blue granules/filaments. Count the number of reticulocytes in 1000 erythrocyte cells.

\section{Measuring the hematocrit value}

The experimental animals were put in a tube with a cover that had a small hole to remove the tail, the tail end of the mice was cleaned with $96 \%$ ethanol, then with scissors that had been sterilized, the tip of the mice was cut $5 \mathrm{~mm}$ from the tail end. Fill the microcapillary pipette with the venous blood ofmice by direct filling with one end covered with wax. Insert the micro capillary tube into a centrifuge (microhematocrit centrifuge), then centrifuge at $1000 \mathrm{rpm}$ for 5 minutes.

\section{Measuring hemoglobin levels}

It calculates the hemoglobin level using a hemoglobin measuring device (brand Easy Touch GHb) by checking the tools to be used, namely the hemoglobin meter installed with a strip and then taking the blood of the experimental animals. Put blood into the hemoglobin strip, then wait 10 seconds, and the examination results will be seen on the Easy Touch GHb monitor.

\section{Data analysis}

The data from this research were processed statistically using IBM SPSS Statistic 22 . The data were tested for normality and then continued with the two-way ANOVA method and the Duncan test.

\section{RESULTS AND DISCUSSION}

The samples used pegagan embun extract with individual dosage variations. Pegagan embun is obtained from Alahan Panjang, West Sumatra. This sample has also been identified in the Herbarium of Andalas University (ANDA) Department of Biology, Faculty of Mathematics and Natural Sciences, Andalas University. With the results of species identification (Hydrocotyle sibthorpioides L.) from the Araliaceae family

The process of making the extract begins with the collection of samples that are still fresh. Furthermore, wet sorting is carried out to separate impurities and foreign material in the sample. Then the sample is washed with running water to remove soil and other adherent impurities. Then the sample is dried by being aerated. The process of making extracts is carried out using the maceration method. The maceration results are evaporated using a rotary evaporator until a thick extract is obtained from the sample. The rotary results received a thick extract of pegagan embun as much as 98.53 grams with a yield of $11.61 \%$.

Extract characterization needs to be done to ensure the quality of the extract used can be met according to standards. The TLC extract profile examination is a qualitative test to determine whether or not there is an identity compound, namely quercetin,because it is known that pegagan embun contains the flavonoid quercetin. The mobile phase used is n-hexane: ethyl acetate with a ratio of $6: 4$. The stationary phase used was silica gel F254. The Rf value obtained is 0.51 (Figure 1). The total ash content obtained from this leaf extract was $18.66 \%$, and the drying shrinkage value obtained from this pegagan embun extract was $8.592 \%$. Based on the phytochemical test, it was found that the ethanol extract of pegagan embun contained flavonoids, phenolics, and saponins.

The experimental animal of male white mice (sex uniform), 2-3 months old (age uniform), this animal is easy to handle, economical, and has physiological and anatomical similarities to humans. Before the 


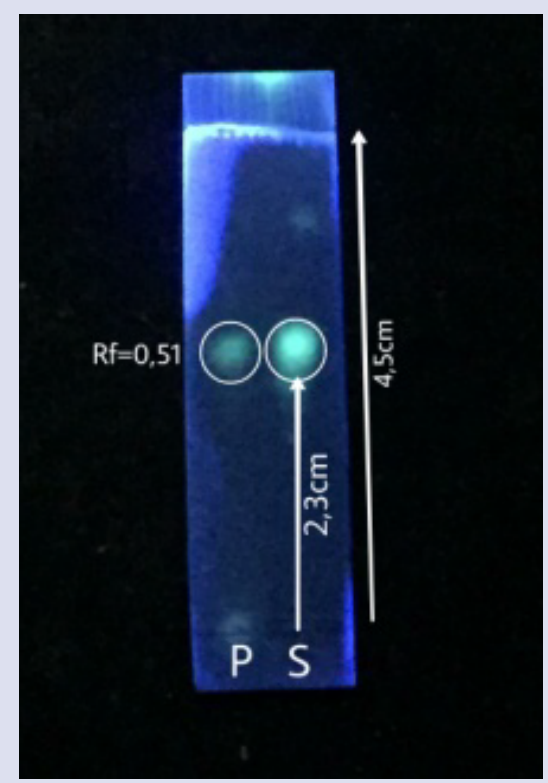

Figure 1: The results of thin-layer chromatography analysis of the ethanol extract of pegagan embun where $P$ : comparison, $\mathrm{S}$ : samples used the mobile phase $n$-hexane: ethyl acetate 6: 4 and the appearance of citroborate stains at a wavelength of $366 \mathrm{~nm}$.

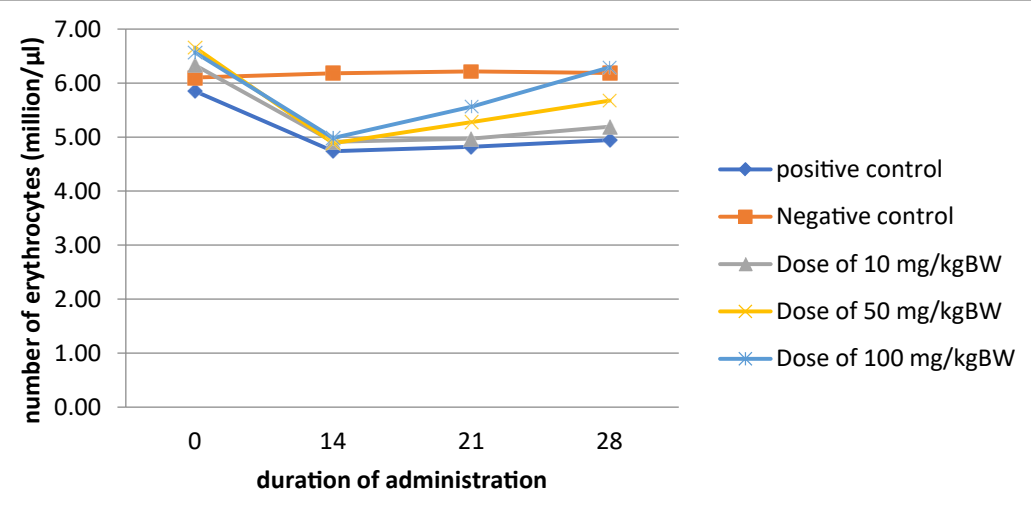

Figure 2: The graph of the relationship between the number of erythrocytes on the day of observation at each dose level after giving the ethanol extract of pegagan embun (Hydrocotyle sibthorpioides L.).

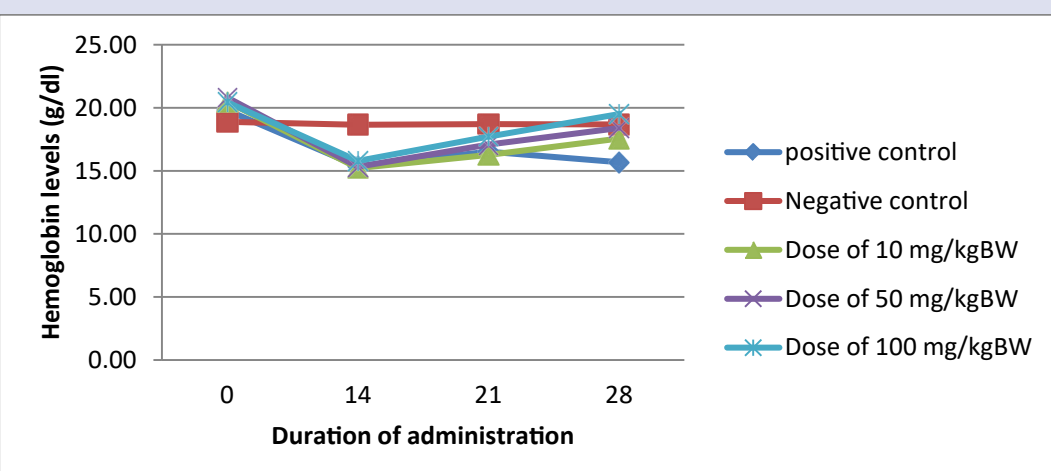

Figure 3: Graph of the relationship between hemoglobin levels on the day of observation at each dose level after giving the ethanol extract of pegagan embun herb (Hydrocotyle sibthorpioides L.). 


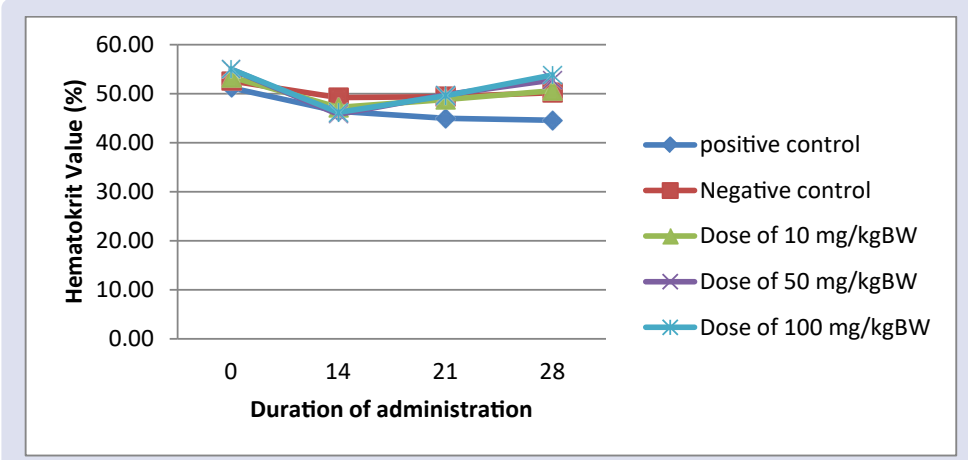

Figure 4: Graph of the relationship between the hematocrit value of the day of observation at each dose level after giving the ethanol extract of pegagan embun (Hydrocotyle sibthorpioides L.).

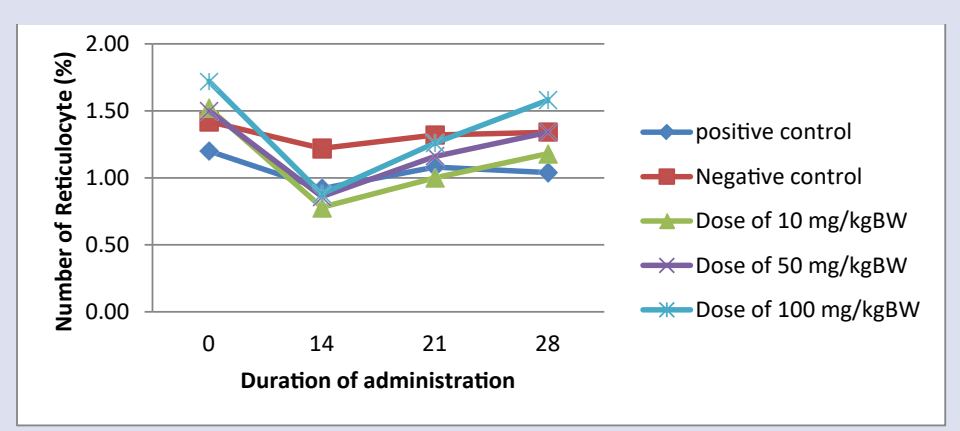

Figure 5: Graph of the relationship between the number of reticulocytes on the day of observation at each dose level after giving ethanol extract of pegagan embun (Hydrocotyle sibthorpioides L.).
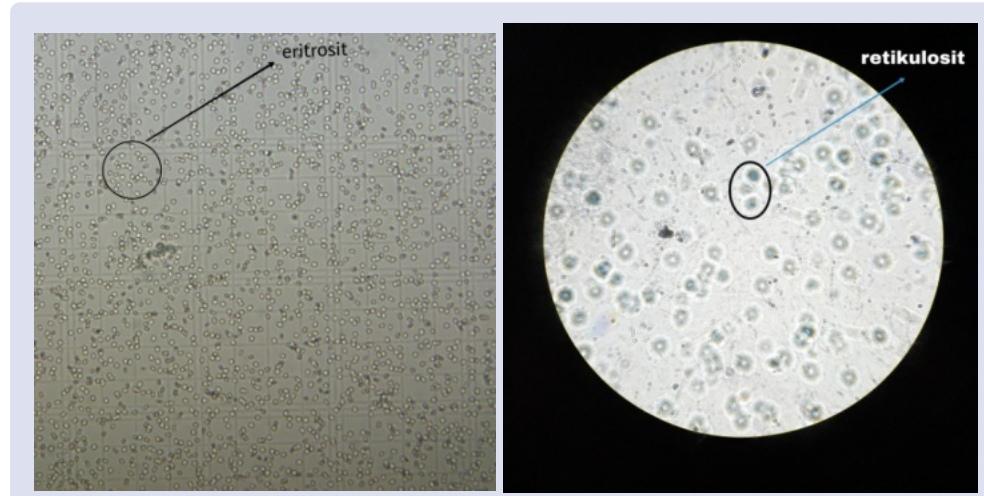

Figure 6: (a) Image of erythrocyte cells, (b) picture of reticulocyte cells.

treatment, the mice were acclimatized before doing the research for 7 days to get used to their new environment so that they were not stressed and to choose healthy mice. In addition, the reason for choosing the experimental animals for male white mice was that the male mice's immune system was not influenced by estrogen hormones as in female mice. To reduce irregularities in the results of the study, mice were selected with the same strain and sex, relatively the same age, and body weight.

In this study, chloramphenicol was used as an inducer of anemia. Chloramphenicol works by suppressing bone marrow, thereby inhibiting bone marrow cells' reproduction and proliferationagainst all red blood cell components that cause aplastic anemia. The parameters tested to see hematopoietic activity consisted of the number of erythrocytes (million/ $\mu \mathrm{l})$, the number of reticulocytes $(\%)$, hemoglobin level $(\mathrm{g} / \mathrm{dl})$, and hematocrit value (\%).

In determining the number of erythrocytes (million/ $\mu$ l) by using a two-way analysis of statistical variance test showed that the number of erythrocytes increased significantly after giving ethanol extract of pegagan embun to all groups of doses, duration of administration, and the interaction between dose and duration of administration $(\mathrm{P}<0.05)$. The increase in the number of erythrocytes in male white mice based on the three doses' variation was the greatest observed at the extract dose of $100 \mathrm{mg} / \mathrm{kg}$, namely 5.85 million $/ \mu \mathrm{l}$. Meanwhile, based on the duration of administration, it was found that it could 
be a greater increase of the number of erythrocytes by giving a more extended preparation. The most significant increasein the number of erythrocytes after administration onthe $28^{\text {th }}$ day was 5.66 million/ $\mu$ il.

From the two-way ANOVA statistical test results, itshowed that the treatment and time factor significantly affects the erythrocyte number of the tested animals. Likewise, there was a significant effect on the erythrocyte number of tested animals with the interaction between treatment and time factor.Duncan's continued test based on the dosage factor and the time of testing showed a significant difference for each time $(\mathrm{P}>0.05)$.

Measuring hemoglobin levels is carried out using the Easy Touch GHb method, the latest digital medical device from Nesco Multicheck, which functions to measure hemoglobin, which is accurate, painless, and easy to use anytime and anywhere. Regarding the accuracy of this tool, it is sufficiently proven because it has passed the test. This tool's accuracy is used as a benchmark in measuring hemoglobin because it is closer to the actual resultsthan other devices ${ }^{17}$. The two-way analysis statistical test results from the administration of ethanol extract of pegagan embun in mice showed that the hemoglobin levels after administration to all dosage groups, the duration of administration, and the interaction between dose and duration of administration increased significantly ( $P$ $<0.05)$. The increase in hemoglobin levels in male white mice based on the three variations in the average was greatest observed at the extract dose of $100 \mathrm{mg} / \mathrm{kg}$, namely $18.36 \mathrm{~g} / \mathrm{dl}$. Meanwhile, based on the duration of administration, the results showed that the provision of a more prolonged dosage could provide a more significant increase in hemoglobin levels. The highest average hemoglobin level after administration on the 28th day was $17.96 \mathrm{~g} / \mathrm{dl}$

From the two-way ANOVA statistical test results,itsindicates that the treatment factor and time have a significant effect on the hemoglobin level of the tested animals. Likewise, with the interaction between treatment factors and time, there was a significant effect on the tested animals' hemoglobin level.In the results of Duncan's continued test based on the dosage factor and the time of the test, it shows a significant difference for each time with a significant value of each sig. $(\mathrm{P}>0.05)$.

Calculation of the hematocrit value is calculated using the micro method, this method was chosen because the amount of blood needed is relatively less so that it can be used for mice. Blood that is put in a microcapillary pipette is centrifuged at a speed of $15000 \mathrm{rpm}$ forfive minutes. The hematocrit value is the volume of all erythrocytes in $100 \mathrm{ml}$ of blood and is called a percent (\%). Calculate the value of the hematocrit aims to help diagnose anemia ${ }^{18}$. According to Bastiawan et al. (2001), if the hematocrit value is low, the number of erythrocytes is low. In calculating the hematocrit value, it was obtained that the ethanol extract of pegagan embun herb in mice that were experiencing anemia against the hematocrit value showed that the results of the two-way analysis of variance statistical test showed that the hematocrit value after giving the ethanol extract of pegagan embun herb to all groups of doses, duration of administration and interaction between doses and the duration of administration increased significantly $(\mathrm{P}<0.05)$. The increase in the hematocrit value in male white mice based on three variations of the average dose was the greatest observed at the extract dose of $100 \mathrm{mg} / \mathrm{kg}$, namely $51.15 \%$. Meanwhile, based on the old factor of administration, the results showed that a longer dosage could provide a greater increase in the hematocrit value. The highest average hematocrit value after administration on the 28 th day was 50.40

From the results of the two-way ANOVA statistical test, it shows that the treatment factor and time significantly affect the hematocrit value of the tested animals. Likewise with the interaction between the treatment factor and time, there was a significant effect on the tested animals' hematocrit value.In Duncan's continued test results based on the dosage factor and the time of testing showed a significant difference for each time with significant values of each being sig $(P>0.05)$.

Blood reticulocyte levels reflect a quantitative measure of erythropoetin ${ }^{19}$. Where is erythropoetin which will stimulate erythroid stem cells to form red blood cell formation materials. So, reticulocyte examination has a crucial clinical role in helping diagnose anemia sufferers. Reticulocytes are young erythrocytes that enter the capillaries through diapedesis (slip through the membrane's pores) ${ }^{20}$. After all of the reticulum is reabsorbed, the cells will become mature erythrocytes. During the development process, reticulocytes in the bone marrow form hemoglobin ${ }^{21}$. So that when the reticulocytes increase, the number of erythrocytes and hemoglobin levels that are formed will also increase. The calculation of reticulocyte value obtained by giving the ethanol extract of the pegagan embunherb to mice who were experiencing anemia against the reticulocyte value showed the results of the twoway variant analysis statistical test showed that the reticulocyte value after giving the ethanol extract of the pegagan embun herb to all dose groups, the duration of administration and the interaction between doses and The duration of administration increased significantly ( $P$ $<0.05)$. In determining the number of reticulocytes, it was found that the increase in the number of reticulocytes in male white mice based on three variations in the average dose was greatest observed at the extract dose of $100 \mathrm{mg} / \mathrm{kgbb}$, namely $1.26 \%$. Meanwhile, based on the length of time of administration, the results showed that the provision of a longer dosage could increase the number of reticulocytes. The highest average reticulocyte count after the 28th day of administration was $1.30 \%$

From the results of the two-way ANOVA statistical test, It shows that the treatment factor and time significantly affect the number of reticulocytes in the tested animals. Likewise, there was a significant effect on the number of reticulocytes in the tested animals with the interaction between treatment factors and time.In Duncan's continued test results based on the dosage factor and the time of testing showed a significant difference for each time with significant values of each being $\operatorname{sig}(\mathrm{P}>0.05)$.

In this study on day 0 , all animals were in a normal state, marked by the number of erythrocytes, reticulocytes, hemoglobin levels and hematocrit values. After being given chloramphenicol induction at a dose of $130 \mathrm{mg} / \mathrm{kgbb}$, these four parameters were seen to decrease and the most significant decrease occurred on day 14. On that day all the above parameters had shown that the animal was in an anemic state. After administration of the ethanol extract suspension of pegagan embun, all dose groups showed an increase as indicated by an increase in the number of erythrocytes, reticulocytes, hemoglobin levels, and hematocrit values. However, not all test parameters with a dose of 100 $\mathrm{mg} / \mathrm{kgbb}$ which is the highest dose have not succeeded in making mice again have an average number of erythrocytes, number of reticulocytes, hemoglobin levels, and normal hematocrit values as in the negative control group.

So from the results obtained, it can be seen that the ethanol extract of the herb pegagan embun can increase the number of erythrocytes, reticulocytes, hemoglobin levels and hematocrit values in male white mice, so that it can be used as an alternative to increase red blood cell components and need to increase the dose in order to maximize haematopoietic activity.

\section{CONCLUSION}

From the results of the study it can be concluded that giving the pegagan embunherb ethanol extract at a dose of $100 \mathrm{mg} / \mathrm{kgbb}, 50 \mathrm{mg} /$ $\mathrm{kgbb}$ and $10 \mathrm{mg} / \mathrm{kgbb}$ orally on the administration from day 15 to day 28 can increase the number of erythrocytes (jt / $\mu \mathrm{l})$, reticulocyte count (\%), hematocrit value (\%) and hemoglobin level ( $\mathrm{g} / \mathrm{dl}$ ) of anemic male white mice, where variations in dose and administration time had a significant effect on the number of anemia male white mice $(\mathrm{P}<0.05)$ 


\section{ACKNOWLEDGMENT}

Profound Thanks towards Research Institution and Community Service (LPPM) of Andalas University, and this research was supported by PNBP ANDALAS UNIVERSITY, Padang, Indonesia, in the scheme of "Penelitian Dasar Unggulan Klaster Riset Publikasi Guru Besar Universitas Andalas (PDU KRP1GB UNAND), Batch I, Year 2021, Contract Number. T/7/UN.16.17/PT.01.03/KO-PDU-KRP1GB/2021 signed on Maret 30th, 2021.

\section{CONFLICTS OF INTEREST}

There are no conflicts and interest in this study.

\section{REFERENCES}

1. Hasanan F. Hubungan Kadar Hemoglobin dengan Daya Tahan Kardiovaskular pada Atlet Atletik FIK Universitas Negeri Makassar. J olahraga dan Kesehat. Published online 2018:1-16.

2. Fitryadi K. Pengenalan Jenis Golongan Darah Menggunakan Jaringan Syaraf Tiruan Perceptron. J Masy Inform. 2016;7.

3. Kusumawardani E. Waspada Penyakit Darah Mengintai Anda. (Kreator H, ed.).; 2010.

4. Departemen Kesehatan RI. Program Penanggulangan Anemia Gizi PadaWanita Usia Subur (WUS); (Safe Motherhood Project: A Partnership AndFamily Approach). Direktorat Jenderl Bina Kesehatan Masyarakat Depkes; 2001.

5. Sukrat B. and Sirichotiyakul S. The prevalence and causes of anemia duringpregnancy in Maharaj Nakorn Chiang Mai Hospital. J Med Assoc Thai. 2006;89:142-146.

6. Arisman. Gizi Dalam Daur Kehidupan. Penerbit Buku Kedokteran EGC; 2010.

7. Aldi, Yufri, Diza Artika MA. Pengaruh pemberian ekstrak etanol meniran (Phyllantus niruri L.) terhadap jumalah eritrosit, retikulosit, kadar hemoglobin dan nilai hematokrit pada mencit putih jantan. Pros Semin Nas dan Work Pelayanan Kefarmasian Herb Med. Published online 2014.
8. Themi H, Diem H HT. Color Atlas of Hematology 2nd Edition. 2nd ed.; 2004.

9. Sudjadi B. Sains Dalam Kehidupan. Yudisthira Ghalia Indonesia; 2006.

10. Corwin E. Buku Saku Patofisiologi. Penerbit Buku Kedokteran EGC; 2009.

11. Admadi Soeroso. Sitokin. J Oftalmol Indones. 2007;5:171-180.

12. Kumari S, Elancheran R, Kotoky J, Devi R. Rapid screening and identification of phenolic antioxidants in Hydrocotyle sibthorpioides Lam . by UPLC - ESI-MS / MS. Food Chem. 2016;203:521-9. doi:10.1016/j.foodchem.2016.02.101

13. Husin F, Chan YY, Gan SH, Sulaiman SA SR. The Effect of Hydrocotyle sibthorpioides Lam. Extracts on In Vitro Dengue Replication. Evidence-Based Complement Altern Med. Published online 2015:1-9.

14. Afriwardi, Aldi Y, Dillasamola D, Larakhansa YA, Badriyya E. Immunostimulatory Activities of Pegagan Embun (Hydrocotyle sibthorpioides Lam.) in White Male Mice. Pharmacog J. 2021;13(2): 368-75.

15. Afriwardi, Nazmi R, Dillasamola D, Badriyya E, AldiY. Anti-inflammatory Activity of Pegagan Embun (Hydrocotyle sibthorpioides Lam.) Plant Extract on Topical Application. Pharmacog J. 2021;13(2): 411-7.

16. Mariani Ria, Atun Qowwiyah, lis Fitryanti. Studi EtnofarmakognosiEtnofarmakologi Tumbuhan Sebagai Obat di Kampung Naga Kecamatan Salawu Kabupaten Tasikmalaya. J Farm Galen. 2015;02 No.1 IS.Tarwoto W. Anemia pada Ibu Hamil (Konsep dan penatalaksanaannya). In: TIM; 2007.

17. Gandasoebrata R. Penuntun Labiratorium Klinik. Dian Rakyat; 2007.

18. Riley RS, Ben-Ezra JM TA. Reticulocyte Enumeration: Laboratory Medicine: Past \& Present.; 2001.

19. Guyton A. Fisiologi Manusia Dan Mekanisme Penyakit Alih Bahasa Oleh. 3rd ed. (alih bahasa oleh Petrus Andrianto., ed.). EGC; 1990.

20. Brugnara C ZD. Reticulocyte hemoglobin content to diagnose iron deficiency in children. JAMA: 2225-30. 


\section{GRAPHICAL ABSTRACT}

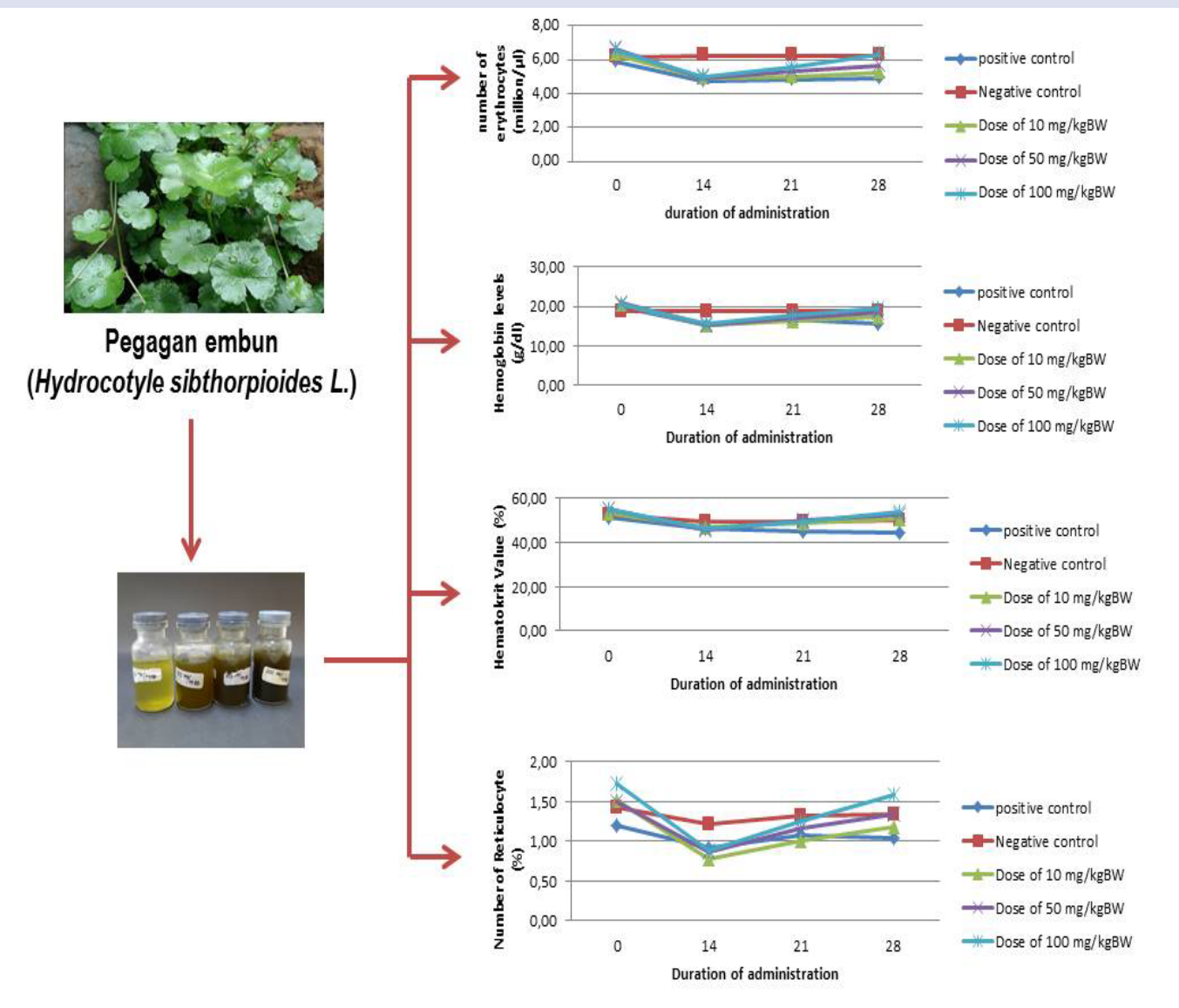

\section{SUMMARY}

Pegagan embun (Hydrocotyle sibthorpioides L.) is known to have many properties, including as a blood booster. This study aims to determine the activity of the pegagan embunherb (Hydrocotyle sibthorpioides L.) on the formation of red blood cells with parameters of the number of erythrocytes, reticulocytes, hemoglobin levels and hematocrit values in male white mice induced by chloramphenicol. This study was observed for 28 days. The first group of experimental animals used were untreated, the second group was induced with $130 \mathrm{mg} / \mathrm{kg}$ of chloramphenicol and the next three groups received 100, 50 and $10 \mathrm{mg}$ / kgbb of ethanol extract of pegagan embun (Hydrocotyle sibthorpioides L.) after previously being induced with $130 \mathrm{mg}$ of chloramphenicol. / kgbb. The experimental animals were induced with chloramphenicol $130 \mathrm{mg} / \mathrm{kg}$ on days 1-14 to experience anemia, then the ethanol extract of the herb pegegan dew was given orally on days 15-28 with various doses. Observations were made on days $0,14,21$ and 28. Based on the research, the factors of dose variation and duration of administration of test preparations had a significant effect on erythrocyte levels, hemoglobin levels, reticulocyte values, and hematocrit values $(\mathrm{P}<0.05)$. With an increase in dosage and duration of administration of pegagan embun herb extract, it can provide a greater increase in hematopoietic parameters.

\section{ABOUT AUTHORS}

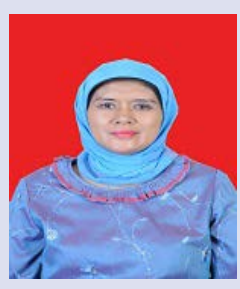

Dr. ElidahanumHusni, Apt.: Dr. ElidahanumHusni, M.Si, Apt.: Currently as a lecturer at the Faculty of Pharmacy, University Andalas. Graduated from Faculty of Pharmacy Universitas Andalas in 1986, then Master Program in 1995 at School of Pharmacy Bandung Institute of Technology and Doctoral Program in Department Biomedical, Faculty of Medicine, University Andalas in 2015. The research and expertise is Pharmacognosy 


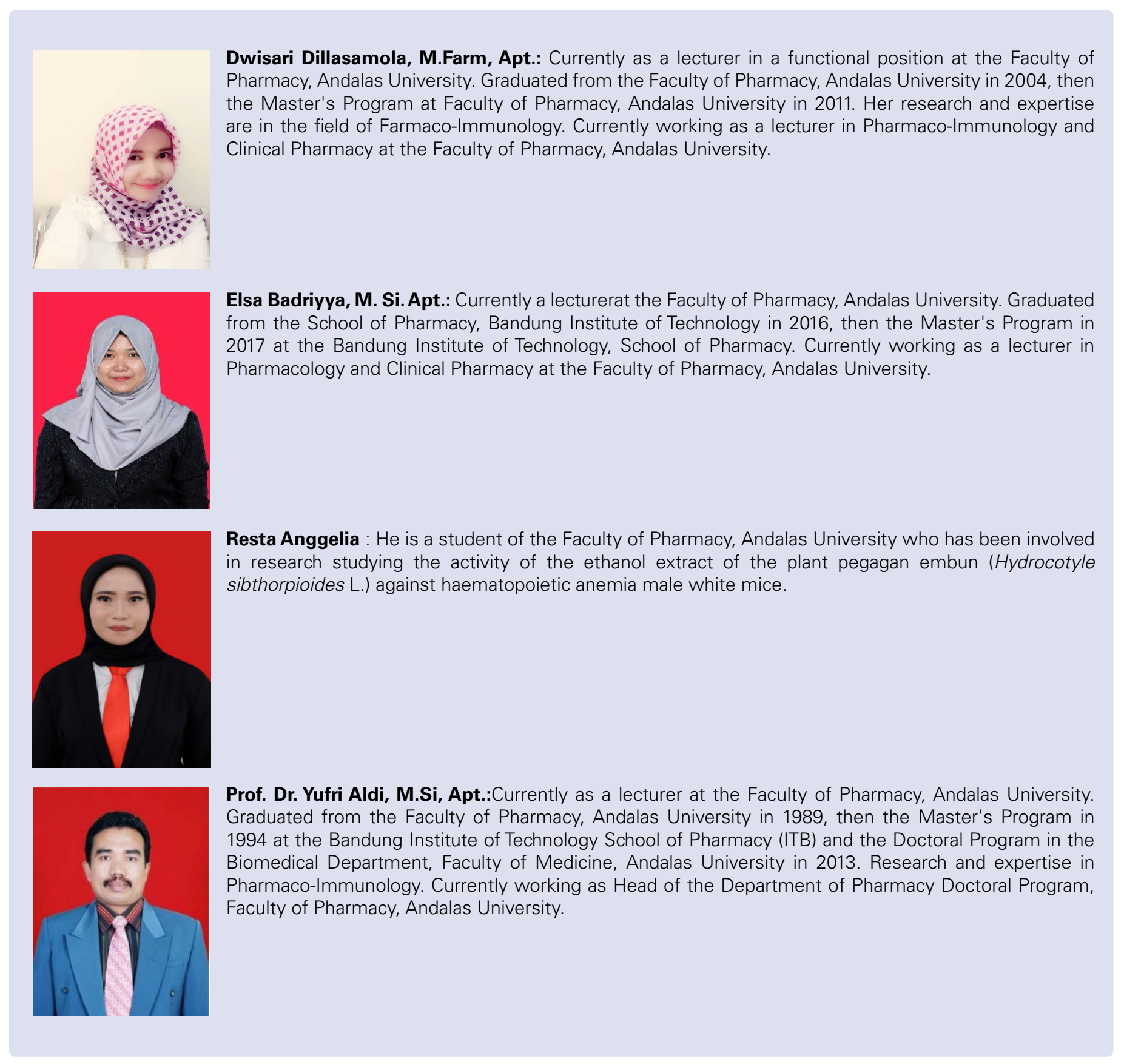

Cite this article: Husni E, Dillasamola D, Badriyya E, Angelia R, Aldi Y. Ethanol Extract Activity of Pegagan Embun (Hydrocotyle sibthorpioides L.) Against Hematopoietic on Anemic Male White Mice. Pharmacog J. 2021;13(4): 866-873. 